\title{
Antibiofilm Activity of Antarctic Sponge-Associated Bacteria against Pseudomonas aeruginosa and Staphylococcus aureus
}

\author{
Carmen Rizzo ${ }^{1}\left(\mathbb{D}\right.$, Vincenzo Zammuto ${ }^{2, *}{ }^{\mathbb{C}}$, Angelina Lo Giudice ${ }^{3,4, *(0)}$, Maria Giovanna Rizzo ${ }^{2}$, Antonio Spanò ${ }^{2}$, \\ Pasqualina Laganà ${ }^{5}$ (D), Miguel Martinez ${ }^{6}$, Salvatore Guglielmino ${ }^{2}$ and Concetta Gugliandolo ${ }^{2}$ (i) \\ 1 Department of Marine Biotechnology, Stazione Zoologica Anton Dohrn, Sicily, Villa Pace Contrada \\ Porticatello 29, 98167 Messina, Italy; carmen.rizzo@szn.it \\ 2 Department of Chemical, Biological, Pharmaceutical and Environmental Sciences, University of Messina, \\ V. le F. Stagno D’Alcontres 31, 98166 Messina, Italy; mgrizzo@unime.it (M.G.R.); aspan@unime.it (A.S.); \\ sguglielm@unime.it (S.G.); cgugliandolo@unime.it (C.G.) \\ 3 Istituto di Scienze Polari, Consiglio Nazionale delle Ricerche (CNR-ISP), Spianata San Raineri 86, \\ 98122 Messina, Italy \\ 4 Museo Nazionale dell'Antartide, Sezione di Messina c/o Università di Messina, \\ Viale F. Stagno d'Alcontres 31, 98166 Messina, Italy \\ 5 Department of Biomedical and Dental Sciences and Morphofunctional Imaging, University of Messina, \\ Torre Biologica, 3p, Policlinico Universitario, Via C. Valeria snc, 98125 Messina, Italy; plagana@unime.it \\ 6 Departamento de Microbiología, Facultad de Ciencias Biológicas, Universidad de Concepción, Casilla 160-C, \\ Concepción 4030000, Chile; mimartin@udec.cl \\ * Correspondence: vzammuto@unime.it (V.Z.); angelina.logiudice@cnr.it (A.L.G.)
}

\section{check for} updates

Citation: Rizzo, C.; Zammuto, V.; Lo Giudice, A.; Rizzo, M.G.; Spanò,

A.; Laganà, P.; Martinez, M.;

Guglielmino, S.; Gugliandolo, C.

Antibiofilm Activity of Antarctic

Sponge-Associated Bacteria against

Pseudomonas aeruginosa and

Staphylococcus aureus. J. Mar. Sci. Eng. 2021, 9, 243. https://doi.org/

$10.3390 /$ jmse 9030243

Academic Editor: Carmela Caroppo

Received: 27 January 2021

Accepted: 20 February 2021

Published: 25 February 2021

Publisher's Note: MDPI stays neutral with regard to jurisdictional claims in published maps and institutional affiliations.

Copyright: (c) 2021 by the authors. Licensee MDPI, Basel, Switzerland This article is an open access article distributed under the terms and conditions of the Creative Commons Attribution (CC BY) license (https:// creativecommons.org/licenses/by/ $4.0 /)$.

\begin{abstract}
Bioprospecting in unusual marine environments provides an innovative approach to search novel biomolecules with antibiofilm activity. Antarctic sponge-associated bacteria belonging to Colwellia, Pseudoalteromonas, Shewanella and Winogradskyella genera were evaluated for their ability to contrast the biofilm formation by Pseudomonas aeruginosa ATCC 27853 and Staphylococcus aureus ATCC 29213, as model organisms. All strains were able to produce biofilm at both 4 and $25{ }^{\circ} \mathrm{C}$, with the highest production being for Colwellia, Shewanella and Winogradskyella strains at $4{ }^{\circ} \mathrm{C}$ after $24 \mathrm{~h}$. Antibiofilm activity of cell-free supernatants (CFSs) differed among strains and on the basis of their incubation temperature $\left(\mathrm{CFSs}_{4}{ }^{\circ} \mathrm{C}\right.$ and $\left.\mathrm{CFSs}_{25^{\circ} \mathrm{C}}\right)$. The major activity was observed by $\mathrm{CFSs}_{4}{ }^{\circ} \mathrm{C}$ against $S$. aureus and $\mathrm{CFSs}_{25^{\circ} \mathrm{C}}$ against $P$. aeruginosa, without demonstrating a bactericidal effect on their growth. Furthermore, the antibiofilm activity of crude extracts from Colwellia sp. GW185, Shewanella sp. CAL606, and Winogradskyella sp. CAL396 was also evaluated and visualized by confocal laser scanning microscopic images. Results based on the surface-coating assay and surface tension measurements suggest that CFSs and the crude extracts may act as biosurfactants inhibiting the first adhesion of P. aeruginosa and S. aureus. The CFSs and the novel biopolymers may be useful in applicative perspectives for pharmaceutical and environmental purposes.
\end{abstract}

Keywords: Antarctic bacteria; biofilm; sponge-associated bacteria

\section{Introduction}

Bacterial adhesion and biofilm formation processes have pervasive importance in environmental and human health. Compared with the free-living style, bacterial aggregations have considerable advantages in terms of self-protection, increasing microbial tolerance to exogenous stresses and the ability to escape to antibiotics or other biocides. Bacterial biofilms by pathogens represent a serious concern in public health, because they are involved in $65-80 \%$ of all human bacterial infections. Persistent infections (such as cystic fibrosis, urethritis, otitis, periodontitis, and endocarditis) have been associated with pathogenic bacteria able to form biofilm settings [1-5]. The biofilm lifestyle protects bacteria from the host immune response and confer them less susceptibility to antimicrobial agents, giving rise to chronic infections that are notoriously difficult to eradicate [6-9]. 
Consequently, the eradication of biofilm appears difficult with traditional pharmaceutical agents, and the exploration of novel anti-biofilm strategies, aimed at searching for new natural valuable compounds to prevent or eliminate biofilm is needed. After an initial attachment, the adhesion to abiotic and biotic surfaces becomes irreversible when the cells begin to secrete exopolymers with the subsequent aggregation of cells into microcolonies, and the formation and stabilization of biofilms [10]. Extracellular polymeric substances (EPSs), also known as exopolymers, mediate most of the cell-to-cell and cell-to-surface interactions that are necessary for the formation and maturation of biofilm [11]. So far more than 30 different biofilm matrix polysaccharides (for example, alginate and cellulose) have been characterized as major component of the biofilm scaffold [11-13]. On the other hand, bacterial exopolymers, including exopolysaccharides, involved in the biofilm formation, could also possess the ability to counteract the adhesion and the biofilm formation of a wide spectrum of bacteria and fungi [14]. Exopolysaccharides might act as signaling molecules that modulate gene expression of recipient bacteria [15], or in the competitive inhibition of multivalent carbohydrate-protein interactions [16].

Marine microorganisms, as free-living or associated with different hosts, represent until now untapped sources of molecules with a broad range of activity including the biofilm inhibition $[17,18]$. Increased attention is given to the discovery of new antibiofilm EPSs with potential applications in different fields, ranging from environmental, such as the inhibition of biofouling on immersed substrates [19] or water treatment and detoxification [20], to the prevention and eradication of biofilm-based infections [4]. Recent findings suggested that the exopolysaccharide produced by the marine thermophilic Bacillus licheniformis T14 possesses the ability to inhibit the biofilm formation of several pathogenic bacteria [18]. This exopolysaccharide did not possess antibacterial effects, suggesting that its antibiofilm activity is therefore mediated by different mechanisms other than growth inhibition. Most antibiofilm exopolymers showed surfactant activities, which influence the physical characteristics of bacterial cells and abiotic surfaces [18].

Among extremophiles, cold-adapted bacteria from polar habitats represent a potential source of structurally and functionally novel biologically active molecules with biotechnological potential [21,22]. Several cold-adapted bacteria of the genera Colwellia, Flavobacterium, Marinobacter, Polaribacter, Pseudoalteromonas, Pseudomonas, Shewanella and Winogradskyella have been reported as able to produce EPSs [23-26]. Pseudoalteromonas is the most frequently reported EPS-producer from Antarctica, mainly from sea-ice and sea-water [22]. Supernatants obtained from cold-adapted bacteria belonging to Pseudoalteromonas, Psychrobacter and Psychromonas were reported able to produce different antibiofilm molecules active against Pseudomonas aeruginosa PAO1, Staphylococcus aureus and S. epidermidis [27]. For instance, a mixture of small hydrophobic molecules, rather than polysaccharides, produced by the Antarctic marine bacterium Pseudoalteromonas haloplanktis TAC125 was reported as active against S. epidermidis biofilm formation [28]. More recently, novel isolates from Antarctic seawater [24,25] and sponge specimens [26] were reported as able to produce EPSs potentially useful in biotechnological applications as cryoprotectant agents.

In this context, the present study was aimed at exploring Antarctic sponge-associated cold-adapted bacteria (in the genera Colwellia, Pseudoalteromonas, Shewanella and Winogradskyella) as producers of antibiofilm agents. Antibiofilm activity was tested against Pseudomonas aeruginosa ATCC 27853 and Staphylococcus aureus ATCC 29213, as biofilm models of clinically significant bacteria.

\section{Materials and Methods}

\subsection{Bacterial Pathogens}

Pseudomonas aeruginosa ATCC 27853 and Staphylococcus aureus ATCC 29213 were purchased from the American Type Culture Collection (LGC Promochem, Milan, Italy). Pseudomonas aeruginosa ATCC 27853 was cultured into Luria Bertani broth (LB) (Sigma Aldrich, St. Louis, MO, USA) and 2\% agarized LB. Staphylococcus aureus ATCC 29213 was 
grown in Tryptone Soya Broth (TSB) (Sigma Aldrich) and Tryptone Soya Agar (TSA) (Sigma Aldrich). Strains were kept frozen at $-80^{\circ} \mathrm{C}$ in $40 \%(v / v)$ glycerol for long term storage.

\subsection{Antarctic Sponge-Associated Bacteria}

Cold-adapted strains used in this work are listed in Table 1. They were previously isolated from Antarctic sponge specimens collected at Terra Nova Bay (Ross Sea, Antarctica) [26,29-31]. Sponge treatment and bacterial isolation procedures were described previously [32]. Strains tested for antibiofilm activity were selected among 1583 isolates for their highly mucous aspect on Marine Agar 2216 (MA; Difco Laboratories, Detroit, MI, USA) plates supplemented with different sugars $(0.6 \%, w / v)$ [26]. Bacterial isolates belong to the Italian Collection of Antarctic Bacteria of the National Antarctic Museum (CIBAN-MNA), kept at the University of Messina (Italy). All strains grow in the temperature value range from 4 to $30{ }^{\circ} \mathrm{C}$. Cultures are routinely grown at $4{ }^{\circ} \mathrm{C}$.

Table 1. Origin of Antarctic sponge-associated bacteria used in this study (na: not assigned).

\begin{tabular}{|c|c|c|c|c|}
\hline Strain & Lab ID & $\begin{array}{c}\text { GenBank } \\
\text { Accession Number }\end{array}$ & Sponge Species & Reference \\
\hline Colwellia sp. MNA-CIBAN-0052 & GW185 & КС709480 & $\begin{array}{l}\text { Hemigellius pilosus } \\
\text { (Kirkpatrick, 1907) }\end{array}$ & {$[30]$} \\
\hline $\begin{array}{l}\text { Pseudoalteromonas sp. } \\
\text { MNA-CIBAN-0059 }\end{array}$ & CAL260 & na & Haliclona dancoi (Topsent, 1901) & {$[31]$} \\
\hline $\begin{array}{l}\text { Pseudoalteromonas sp. } \\
\text { MNA-CIBAN-0118 }\end{array}$ & CAL416 & na & Tedania charcoti (Topsent, 1907) & [31] \\
\hline $\begin{array}{l}\text { Pseudoalteromonas sp. } \\
\text { MNA-CIBAN-0117 }\end{array}$ & CAL433 & na & Tedania charcoti (Topsent, 1907) & [31] \\
\hline $\begin{array}{l}\text { Pseudoalteromonas sp. } \\
\text { MNA-CIBAN- } 0123\end{array}$ & CAL451 & na & Haliclona virens (Topsent, 1908) & {$[31]$} \\
\hline $\begin{array}{l}\text { Pseudoalteromonas sp. } \\
\text { MNA-CIBAN-0090 }\end{array}$ & TB42 & JF273855 & $\begin{array}{l}\text { Anoxycalyx (Scolymastra) joubini } \\
\text { (Topsent, 1916) }\end{array}$ & [29] \\
\hline Shewanella sp. MNA-CIBAN-0172 & CAL242 & na & Haliclona sp. & {$[31]$} \\
\hline Shewanella sp. MNA-CIBAN-0521 & CAL62 & na & Calyx arcuarius (Topsent, 1913) & [31] \\
\hline Shewanella sp. MNA-CIBAN-0158 & CAL606 & JF273931 & $\begin{array}{l}\text { Haliclonissa verrucosa } \\
\text { (Burton, 1932) }\end{array}$ & [29] \\
\hline Winogradskyella sp. MNA-CIBAN-0261 & CAL384 & KX108853 & Tedania charcoti (Topsent, 1907) & [26] \\
\hline Winogradskyella sp. MNA-CIBAN-0263 & CAL396 & KX108854 & Tedania charcoti (Topsent, 1907) & [26] \\
\hline
\end{tabular}

\subsection{Biofilm Formation Assay}

Biofilm formation by P. aeruginosa ATCC 27853 and S. aureus ATCC 29213 was investigated in 96-well polystyrene microplates (Falcon ${ }^{\circledR}$, Fisher Scientific, Milan, Italy), as previously reported by $\mathrm{O}^{\prime}$ Toole et al. [33]. Suitable aliquots $(200 \mu \mathrm{L})$ of each overnight culture in LB or TSB $\left(\mathrm{OD}_{600 \mathrm{~nm}}=0.1\right.$ equivalent to $1.5 \times 10^{8}$ bacteria $\left./ \mathrm{mL}\right)$ were poured in the microwells and the microplates were incubated at $37^{\circ} \mathrm{C}$ for $48 \mathrm{~h}$ (for P. aeruginosa) or $24 \mathrm{~h}$ (for $S$. aureus), without shaking. Nonadherent bacteria were removed by washing 5 times with distilled water, by gentle aspiration. Biofilms were stained with $0.1 \%(w / v)$ crystal violet solution for $20 \mathrm{~min}$. Excess stain was removed by aspiration, and the plates were washed (5 times) and air dried (for $45 \mathrm{~min}$ ). The stained biofilms were solubilized with absolute ethanol. Biofilm mass was spectrophotometrically determined $\left(\mathrm{OD}_{585 \mathrm{~nm}}\right)$ by the level of the crystal violet present in the de-staining solution, using a microtiter plate reader (Multiskan GO, Thermo Scientific, Waltham, MA, USA). Each data point was averaged from eight replicated microwells, and the standard deviation (SD) was calculated. 
To investigate the biofilm formation by Antarctic sponge-associated bacteria, strains were cultivated in a broth medium prepared with the Väätänen nine-salt solution (VNSS) [34], plus $0.05 \%$ peptone $(w / v), 0.01 \%$ yeast extract $(w / v)$ and $2 \%$ sucrose $(w / v)$ as carbon source (VNSS+PYS). VNSS composition per liter of distilled water was as follows: $\mathrm{NaCl} 17.6 \mathrm{~g}$, $\mathrm{Na}_{2} \mathrm{SO}_{4} 1.47 \mathrm{~g}, \mathrm{NaHCO}_{3} 0.08 \mathrm{~g}, \mathrm{KCl} 0.25 \mathrm{~g}, \mathrm{KBr} 0.04 \mathrm{~g}, \mathrm{MgCl}_{2} \cdot 6 \mathrm{H}_{2} \mathrm{O} 1.87 \mathrm{~g}, \mathrm{CaCl}_{2} \cdot 2 \mathrm{H}_{2} \mathrm{O}$ $0.41 \mathrm{~g}$, $\mathrm{SrCl} \cdot 6 \mathrm{H}_{2} \mathrm{O} 0.008 \mathrm{~g}, \mathrm{H}_{3} \mathrm{BO}_{3} 0.008 \mathrm{~g}$.

As reported above, suitable aliquots $(200 \mu \mathrm{L})$ of each overnight culture in VNSS+PYS $\left(\mathrm{OD}_{600 \mathrm{~nm}}=0.1\right.$, equivalent to $1.5 \times 10^{8}$ bacteria $\left./ \mathrm{mL}\right)$ were poured in the microwells and the microplates were incubated at $4{ }^{\circ} \mathrm{C}$ for $96 \mathrm{~h}$ or $25^{\circ} \mathrm{C}$ for $48 \mathrm{~h}$, without shaking. To evaluate the biofilm masses the microplates were treated as described above.

\subsection{Cell-Free-Supernatants from Antarctic Sponge-Associated Bacteria}

Aliquots $(10 \%, v / v)$ of each bacterial culture in the exponential growth phase were inoculated into $25 \mathrm{~mL}$ medium VNSS+PYS, and cultures were incubated at $4{ }^{\circ} \mathrm{C}$ for 4 days or at $25^{\circ} \mathrm{C}$ for $48 \mathrm{~h}$. In order to remove all bacterial cells, cultures were centrifuged at $10,000 \times g$ for $30 \mathrm{~min}$, and each supernatant was filtered through a $0.2-\mu \mathrm{m}$-pore-size membrane (Sartorius, Göttingen, Germany). Aliquots of $100 \mu \mathrm{L}$ of each cell-free supernatant $\left(\mathrm{CFS}_{4}{ }^{\circ} \mathrm{C}\right.$ and $\mathrm{CFS}_{25^{\circ} \mathrm{C}}$ from bacterial cultures incubated at 4 and $25^{\circ} \mathrm{C}$, respectively) were spreadplated onto MA plates at 4 and $25^{\circ} \mathrm{C}$ for 4 and 2 days, respectively to ensure that no cells remained in each supernatant.

\subsection{Antibiofilm Activity}

\subsubsection{Cell Free Supernatants}

CFSs obtained from bacterial isolates were evaluated for their capacity to inhibit biofilm formation by P. aeruginosa and S. aureus in 96-well polystyrene microplates, as previously reported $[18,33]$. Aliquots $(20 \mu \mathrm{L})$ of each CFS were added (final concentration $10 \%, v / v)$ to $180 \mu \mathrm{L}$ of overnight cultures of the two pathogens in $\mathrm{TSB}\left(\mathrm{OD}_{600 \mathrm{~nm}}=0.1\right.$, equivalent to $1.5 \times 10^{8}$ bacteria $/ \mathrm{mL}$ ), and microplates were incubated at $37^{\circ} \mathrm{C}$ for $48 \mathrm{~h}$ (P. aeruginosa) or $24 \mathrm{~h}$ (S. aureus) without shaking and treated as described above. The reduction of biofilm formation by each pathogenic strain was expressed as antibiofilm activity (\%) by applying the following formula: $\left(\mathrm{OD}_{\text {control }}-\mathrm{OD}_{\text {sample }} / \mathrm{OD}_{\text {control }}\right) \times 100$. Each data point was averaged from eight replicated wells, and the SD was calculated.

\subsubsection{Crude Extracts}

The antibiofilm activity against the two pathogens was evaluated for the crude extracts obtained from the most active CFSs. Crude extracts from CFSs were obtained as reported previously [26]. Briefly, after centrifugation $\left(8000 \times \mathrm{g}\right.$ for $10 \mathrm{~min}$ at $\left.4{ }^{\circ} \mathrm{C}\right)$, the supernatant was treated with 1 volume of cold absolute ethanol added under stirring. Crude extracts were obtained by centrifugation and the pellets were dissolved in hot water. The final water solution was dialyzed against tap water and distilled water, and then freeze-dried.

In 96-well microtiter plates, $20 \mu \mathrm{L}$ of each crude extract diluted in Phosphate Buffer Saline (PBS) (Sigma Aldrich) at final concentration of 100, 200 or $400 \mu \mathrm{g} / \mathrm{mL}$, or $20 \mu \mathrm{L}$ of PBS as control, were added to overnight cultures $(180 \mu \mathrm{L})$ of P. aeruginosa or S. aureus $\left(\mathrm{OD}_{600 \mathrm{~nm}}=0.1\right)$ and plates were incubated at $37^{\circ} \mathrm{C}$ for $48 \mathrm{~h}($. aeruginosa $)$ or $24 \mathrm{~h}$ (S. aureus). OD6 $00 \mathrm{~nm}$ values were recorded after $24 \mathrm{~h}$ or $48 \mathrm{~h}$, and antibiofilm capacity of the crude extracts was evaluated as described above.

The reduction of biofilm formation by each pathogenic strain was expressed as antibiofilm activity (\%), calculated as described above. Each data point was averaged from four replicated wells and the SD was calculated.

\subsection{Surface Coating Assay}

A volume of $50 \mu \mathrm{L}$ of each CFS or $20 \mu \mathrm{L}$ of each crude extract diluted in PBS (400 $\mu \mathrm{g} / \mathrm{mL}$ final concentration) were transferred to the center of a 24-well polystyrene microtiter plate (Falcon no. 353047) [35]. The plates were incubated at $37^{\circ} \mathrm{C}$ for $30 \mathrm{~min}$ to 
allow complete water evaporation. The wells were filled with $1 \mathrm{~mL}$ of diluted overnight cultures containing $10^{5} \mathrm{CFU} / \mathrm{mL}$ of P. aeruginosa or S. aureus in LB and TSB, respectively, and the plates were incubated at $37^{\circ} \mathrm{C}$ for $18 \mathrm{~h}$, in static conditions. Wells were washed (two times) with distilled water and stained with $1 \mathrm{~mL}$ of $0.1 \%$ crystal violet solution. To remove the excess of crystal violet, stained biofilms were rinsed with distilled water and air dried, and finally the wells were photographed.

\subsection{Surface Tension}

Surface tension (ST) of each CFS was measured by using a Digital Tensiometer Gibertini Elettronica ${ }^{\mathrm{TM}}$ TSD (Gibertini Elettronica, Milan, Italy) by the Wilhelmy Plate method, as previously described [36]. A ST lower than $40 \mathrm{mN} / \mathrm{m}$ was considered as an expression of biosurfactant production $[37,38]$.

\subsection{Confocal Microscopic Observation}

Aliquots $(800 \mu \mathrm{L})$ of P. aeruginosa (in LB) or S. aureus (in TSB) overnight cultures (adjusted to $\mathrm{OD}_{600 \mathrm{~nm}}=0.1$ ) were poured in a 24 well plates (Falcon) with inside sterilized round microscope glass cover slides coverslips (18 $\mathrm{mm}$ in diameter). After the addition of $200 \mu \mathrm{L}$ of each crude extract diluted in PBS ( $400 \mu \mathrm{g} / \mathrm{mL}$ final concentration), plates were incubated at $37^{\circ} \mathrm{C}$ for $24 \mathrm{~h}$ (for S. aureus) or $48 \mathrm{~h}$ (for P. aeruginosa). Not-attached bacteria were removed by washing with PBS, and the adherent cells on the coverslip were heat-fixed and stained with $20 \mu \mathrm{g} / \mathrm{mL}$ of propidium iodide (PI, Sigma Aldrich).

Coverslips were incubated in the dark at $30{ }^{\circ} \mathrm{C}$ for $5 \mathrm{~min}$. Biofilm formation of P. aeruginosa and S. aureus were observed using the Confocal Laser Scanning Microscopy (CLSM) to TCS SP2 microscope (Leica Microsystems Heidelberg, Mannheim, Germany), equipped with $\mathrm{Ar} / \mathrm{Kr}$ laser, and coupled to a microscope (Leica DMIRB).

\section{Results}

\subsection{Biofilm Formation Assay}

All tested Antarctic sponge-associated bacterial showed the biofilm-forming ability (Table 2).

Table 2. Biofilm formation by Antarctic sponges-associated bacterial strains incubated at $4{ }^{\circ} \mathrm{C}$ for $96 \mathrm{~h}$, or at $25^{\circ} \mathrm{C}$ for $48 \mathrm{~h}$, and P. aeruginosa and S. aureus after incubation at $37^{\circ} \mathrm{C}$ for $48 \mathrm{~h}$ and $24 \mathrm{~h}$, respectively. Each value was obtained by four independent experiments performed in triplicate. Standard deviations are reported ( ${ }^{a}$ : incubation temperature $\left.37^{\circ} \mathrm{C}\right)$.

\begin{tabular}{ccc}
\hline Strain & \multicolumn{2}{c}{ Biofilm Formation $\left(\mathbf{O D}_{\mathbf{5 8 5} \mathbf{~ n m})}\right.$} \\
\cline { 2 - 3 } & $\mathbf{4}^{\circ} \mathbf{C}$ & $\mathbf{2 5}{ }^{\circ} \mathbf{C}$ \\
\hline Colwellia sp. GW185 & $1.16 \pm 0.04$ & $0.65 \pm 0.01$ \\
Pseudoalteromonas sp. CAL260 & $0.60 \pm 0.04$ & $0.41 \pm 0.01$ \\
Pseudoalteromonas sp. CAL416 & $0.51 \pm 0.03$ & $0.42 \pm 0.01$ \\
Pseudoalteromonas sp. CAL451 & $0.61 \pm 0.06$ & $0.44 \pm 0.01$ \\
Pseudoalteromonas sp. CAL433 & $0.60 \pm 0.05$ & $0.41 \pm 0.01$ \\
Pseudoalteromonas sp. TB42 & $0.60 \pm 0.06$ & $0.41 \pm 0.01$ \\
Shewanella sp. CAL62 & $0.92 \pm 0.14$ & $0.67 \pm 0.07$ \\
Shewanella sp. CAL242 & $0.98 \pm 0.09$ & $0.67 \pm 0.07$ \\
Shewanella sp. CAL606 & $1.00 \pm 0.08$ & $0.67 \pm 0.07$ \\
Winogradskyella sp. CAL384 & $0.92 \pm 0.08$ & $0.54 \pm 0.06$ \\
Winogradskyella sp. CAL396 & $0.99 \pm 0.08$ & $0.56 \pm 0.08$ \\
\hline Pseudomonas aeruginosa ATCC27853 & $2.10 \pm 0.08^{\text {a }}$ & \\
Staphylococcus aureus ATCC29213 & $1.12 \pm 0.07^{\text {a }}$ & \\
\hline
\end{tabular}

Overall, biofilm masses produced at $25^{\circ} \mathrm{C}$ were lower than at $4{ }^{\circ} \mathrm{C}$. The best biofilm production was observed for Colwellia sp. GW185, followed by Shewanella sp. CAL606 and 
Winogradskyella sp. CAL396. Pseudoalteromonas isolates resulted less efficient in biofilm formation than the other tested strains.

\subsection{Antibiofilm Activity of CFSs}

The antibiofilm activity of $\mathrm{CFSs}_{4}{ }^{\circ} \mathrm{C}$ and $\mathrm{CFSs}_{25^{\circ} \mathrm{C}}$ from Antarctic strains against P. aeruginosa and S. aureus is shown in Figure 1. Overall, the presence of CFSs did not significantly influenced the growth values of P. aeruginosa and S. aureus, thus indicating the absence of any antibacterial activity (Figure S1).

(a)

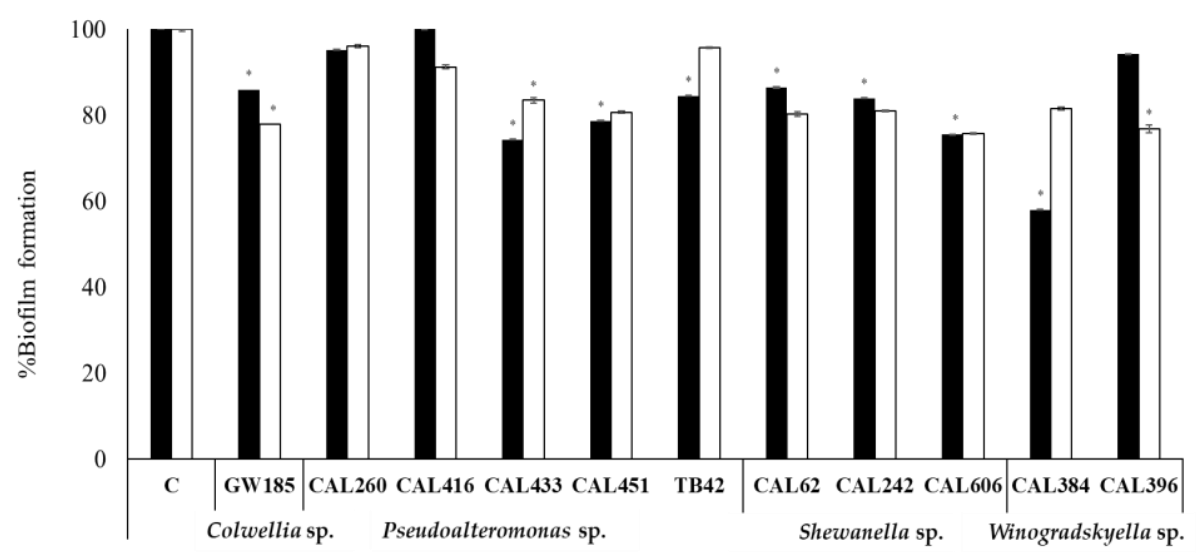

(b)

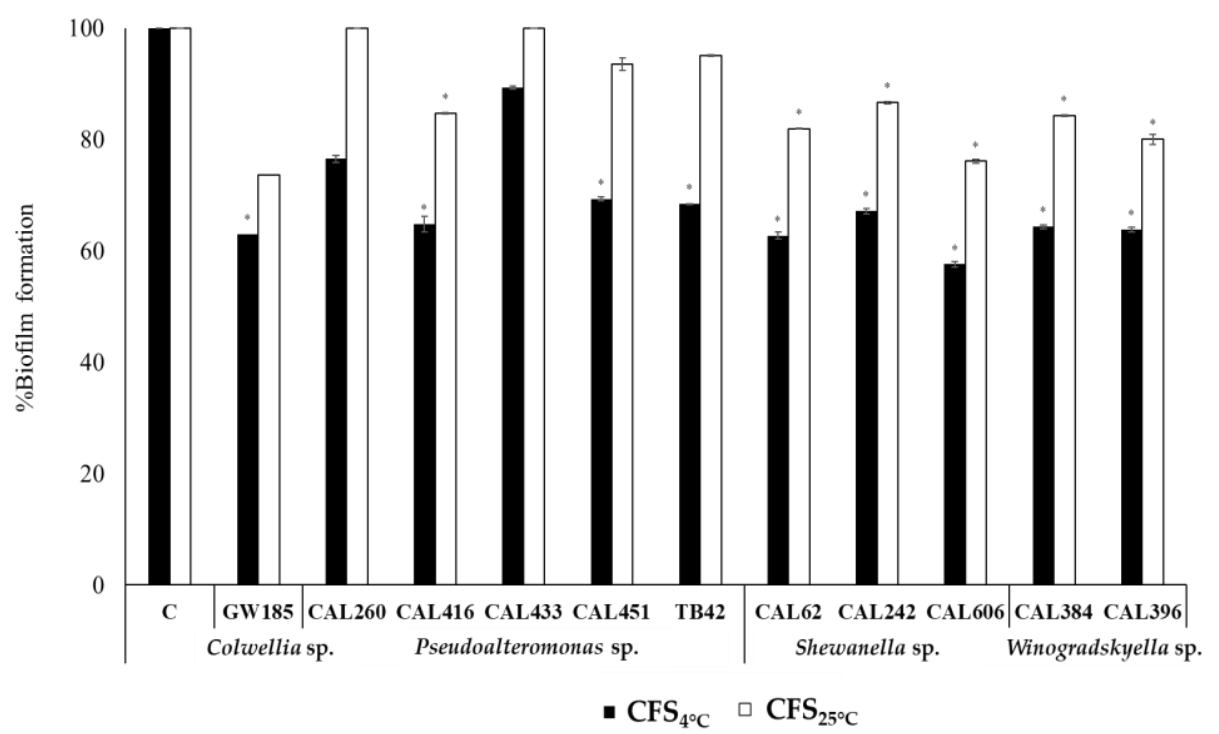

Figure 1. Biofilm formation (\%) of P. aeruginosa ATCC 27853 (a) and S. aureus ATCC 29213 (b) after $48 \mathrm{~h}$ and $24 \mathrm{~h}$ treatment, respectively, in absence (Control, C) or in presence of CFSs from Antarctic sponges-associated bacteria obtained after incubation at $4\left(\mathrm{CFS}_{4}{ }^{\circ} \mathrm{C}\right.$ black bars) or $25^{\circ} \mathrm{C}\left(\mathrm{CFS}_{25^{\circ} \mathrm{C}}\right.$, white bars). The data were analyzed by One-way ANOVA. Statistically significant differences $(p \leq 0.05)$ between the control $(\mathrm{C})$ and treated samples are indicated by an asterisk $\left(^{*}\right)$. Refer to Table 1 for bacterial strain affiliation.

The antibiofilm activity of CFSs differed among the tested strains and also between strains belonging to the same genus on the base of the incubation temperature $\left(4\right.$ or $\left.25^{\circ} \mathrm{C}\right)$. All CFSs exhibited antibiofilm activity against $P$. aeruginosa, although at different extents (Figure 1a). $\mathrm{CFSS}_{4}{ }^{\circ} \mathrm{C}$ showed a biofilm reduction ranging from 2.1 (Pseudoalteromonas CAL416) to $42.1 \%$ (Winogradskyella CAL384), whereas $\mathrm{CFSs}_{25^{\circ} \mathrm{C}}$ reduced the biofilm pro- 
duction from 3.9\% (Pseudoalteromonas CAL260) to 28.5\% (Shewanella CAL606). A moderate antibiofilm activity, expressed as biofilm reduction $\geq 20 \%$, was observed for $\mathrm{CFSs}_{4}{ }^{\circ} \mathrm{C}$ from Pseudoalteromonas sp. CAL451 and CAL433 (21.4 and 25.8\%, respectively), and for CFSs $25^{\circ} \mathrm{C}$ from Colwellia GW185, Winogradskyella CAL396, and Shewanella CAL606 (22.2, 23.2 and $28.5 \%$, respectively).

The biofilm reduction against $S$. aureus was observed for all $\mathrm{CFSs}_{4}{ }^{\circ} \mathrm{C}$ (Figure 1b). Most of $\mathrm{CFSs}_{4}{ }^{\circ} \mathrm{C}$ exhibited a biofilm reduction $\geq 20 \%$, with the only exception of Pseudoalteromonas CAL433 $(10.7 \%)$. The highest inhibition activity was shown by the $\mathrm{CFS}_{4}{ }^{\circ} \mathrm{C}$ obtained from Shewanella sp. CAL606 (42.4\%). With the exception of $\mathrm{CFSs}_{25^{\circ} \mathrm{C}}$ from Pseudoalteromonas sp. strains TB42, CAL260 and CAL433, all the other CFSs were able to reduce the S. aureus biofilm formation. A moderate activity was observed for $\mathrm{CFSs}_{25} 5^{\circ} \mathrm{C}$ from Winogradskyella CAL396, Shewanella CAL606 and Colwellia GW185 (range 20.0-26.3\%).

\subsection{Surface Coating Assay with CFSs}

Most of CFSs were able to prevent the adhesion of P. aeruginosa and S. aureus to polystyrene surfaces after $18 \mathrm{~h}$ treatment, with the only exception of Pseudoalteromonas CAL260 (Table 3 and Figure S2). Overall, $\mathrm{CFSs}_{4}{ }^{\circ} \mathrm{C}$ were numerically less active $(4 / 11)$ than $\mathrm{CFSs}_{25^{\circ} \mathrm{C}}$ against both P. aeruginosa and S. aureus; however, each CFS showed a different pattern of action. For instance, CFSs from Pseudoalteromonas sp. CAL416 contrasted the adhesion of $P$. aeruginosa but not of $S$. aureus. $\mathrm{CFSs}_{25^{\circ} \mathrm{C}}$ from Pseudoalteromonas sp. strains CAL433 and CAL451 were active only against S. aureus, whereas $\mathrm{CFSs}_{25^{\circ} \mathrm{C}}$ from Pseudoalteromonas sp. TB42 and Shewanella CAL62 were active only against P. aeruginosa.

Table 3. Inhibition of Pseudomonas aeruginosa and Staphylococcus aureus adhesion to polystyrene surfaces in absence (Control) or pre-coated with CFSs from Antarctic sponges-associated bacteria obtained after incubating at $4{ }^{\circ} \mathrm{C}\left(\mathrm{CFS}_{4}{ }^{\circ} \mathrm{C}\right)$ or $25^{\circ} \mathrm{C}\left(\mathrm{CFS}_{25^{\circ}} \mathrm{C}\right)$, after a $18 \mathrm{~h}$ treatment.

\begin{tabular}{|c|c|c|c|c|}
\hline \multirow[b]{2}{*}{ CFS } & \multicolumn{2}{|c|}{ P. aeruginosa ATCC 27853} & \multicolumn{2}{|c|}{ S. aureus ATCC 29213} \\
\hline & $4^{\circ} \mathrm{C}$ & $25^{\circ} \mathrm{C}$ & $4^{\circ} \mathrm{C}$ & $25^{\circ} \mathrm{C}$ \\
\hline Control & - & - & - & - \\
\hline Colwellia sp. GW185 & - & + & + & + \\
\hline Pseudoalteromonas sp. CAL260 & - & - & - & - \\
\hline Pseudoalteromonas sp. CAL416 & + & + & - & - \\
\hline Pseudoalteromonas sp. CAL433 & - & - & - & + \\
\hline Pseudoalteromonas sp. CAL451 & - & - & - & + \\
\hline Pseudoalteromonas sp. TB42 & - & + & - & - \\
\hline Shewanella sp. CAL62 & - & + & - & - \\
\hline Shewwanella sp. CAL242 & - & + & + & + \\
\hline Shewwanella sp. CAL606 & + & + & + & + \\
\hline Winogradskyella sp. CAL384 & + & + & - & + \\
\hline Winogradskyella sp. CAL396 & + & + & + & + \\
\hline
\end{tabular}

$(+)=$ inhibition of adhesion to polystyrene; $(-)=$ negative capacity of inhibition of adhesion to polystyrene.

CFSs from Colwellia sp. GW185 and Shewanella sp. strains CAL242 showed a similar pattern of action against the adhesion of the two pathogens. Finally, CFSs obtained from Shewanella CAL606 and Winogradskyella sp. CAL396 after incubation at both the temperature tested $\left(4\right.$ and $25{ }^{\circ} \mathrm{C}$ ) were able to contrast the adhesion of P. aeruginosa and S. aureus on polystyrene surfaces.

\subsection{Surface Tension of CFSs}

Almost all CFSs significantly reduced $(p \leq 0.05)$ the ST of the water $(72.8 \mathrm{mN} / \mathrm{m}$ at $20{ }^{\circ} \mathrm{C}$ ) (Figure 2). $\mathrm{CFSs}_{4}{ }^{\circ} \mathrm{C}$ lowered ST values in the range from 53.4 (Pseudoalteromonas $\mathrm{sp}$. CAL260) to $62.5 \mathrm{mN} / \mathrm{m}$ (Pseudoalteromonas sp. CAL451), whereas $\mathrm{CFSs}_{25^{\circ} \mathrm{C}}$ from 42.3 (Shewanella sp. CAL242) to $51.9 \mathrm{mN} / \mathrm{m}$ (Pseudoalteromonas sp. CAL451), with the major difference between $\mathrm{CFS}_{4}{ }^{\circ} \mathrm{C}$ and $\mathrm{CFSs}_{25^{\circ} \mathrm{C}}$ from Shewanella sp. CAL242 and Winogradskyella sp. CAL384. $\mathrm{CFSs}_{25^{\circ} \mathrm{C}}$ were more active than $\mathrm{CFS}_{4}{ }^{\circ} \mathrm{C}$, because the ST of the water was de- 
creased more than $30 \%$, with the CFS from Shewanella sp. CAL606 (41.8\% of ST reduction) being the most active, followed by Pseudoalteromonas sp. CAL451 and Winogradskyella sp. CAL384 (Figure 2).

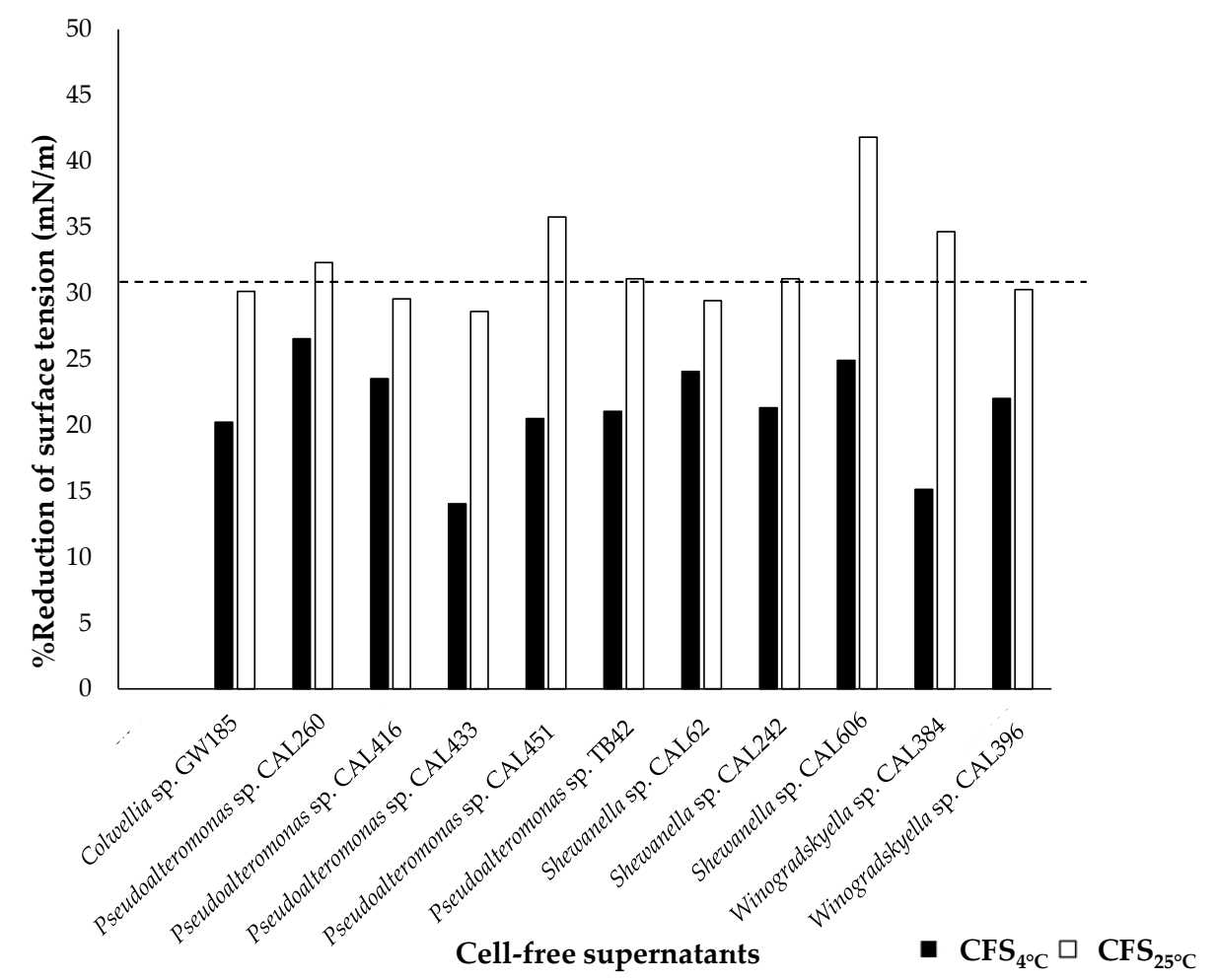

Figure 2. Reduction of the surface tension (ST) of water by $\mathrm{CFSs}_{4}{ }^{\circ} \mathrm{C}$ and $\mathrm{CFSs}_{25^{\circ} \mathrm{C}}$ obtained from Antarctic sponges-associated bacteria. Reduction of ST was considered unaffected below 30\%.

\subsection{Antibiofilm of Crude Extracts}

A slight reduction $(\leq 10 \%)$ of biofilm formation of P. aeruginosa ATCC 27,853 and S. aureus ATCC 2913 was observed by all the crude extracts. The highest reduction was observed in the presence of the crude extracts $(400 \mu \mathrm{g} / \mathrm{mL})$ from $\mathrm{CFS}_{25^{\circ} \mathrm{C}}$ of Colwellia sp. GW185 and $\mathrm{CFSs}_{4}{ }^{\circ} \mathrm{C}$ Shewanella sp. CAL606 and Winogradskyella sp. CAL396 (Figure 3).
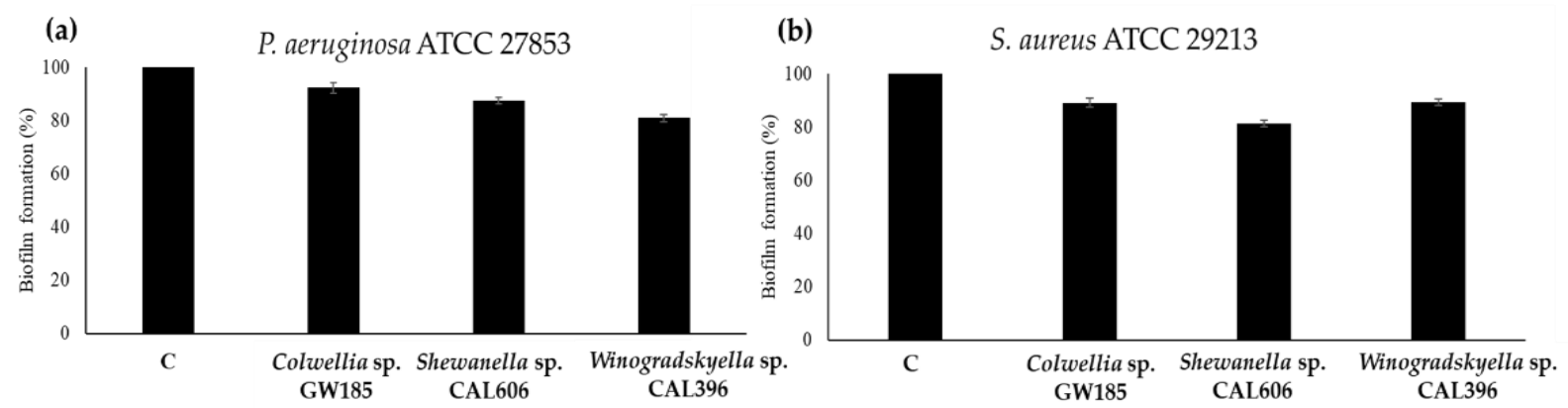

Figure 3. Biofilm formation by (a) P. aeruginosa and (b) S. aureus, after $48 \mathrm{~h}$ and $24 \mathrm{~h}$ treatment, respectively, in absence (Control, C) or in presence of crude extracts $(400 \mu \mathrm{g} / \mathrm{mL})$ from Colwellia sp. GW185, Winogradskyella sp. CAL396 and Shewanella sp. CAL606.

The highest antibiofilm activity of crude extracts against $P$. aeruginosa was observed for Winogradskyella sp. CAL396 (19.0\%), followed by Shewanella sp. CAL606 (12.6\%), whereas against S. aureus was observed for Shewanella sp. CAL606 (18.6\%), followed by Winogradskyella sp. CAL396 (16.7\%). 


\subsection{Surface Coating Assay with Crude Extracts}

Only the crude extract from Shewanella sp. CAL606 was able to contrast the adhesion of $P$. aeruginosa and S. aureus to polystyrene surfaces, while those from Colwellia sp. GW185 and Winogradskyella CAL396 were active against P. aeruginosa (Table 4 and Figure S3).

Table 4. P. aeruginosa and S. aureus adhesion to polystyrene in absence (Control) or pre-coated surfaces with crude extract $(400 \mu \mathrm{g} / \mathrm{mL})$ from Colwellia sp. GW185, Shewanella sp. CAL606 and Winogradskyella sp. CAL396 after $18 \mathrm{~h}$ treatment.

\begin{tabular}{ccc}
\hline Crude Extract & P.aeruginosa ATCC 27853 & S.aureus ATCC 29213 \\
\hline Control & - & - \\
Colwellia sp. GW185 & + & - \\
Shewanella sp. CAL606 & + & - \\
Winogradskyella sp. CAL396 & + & + \\
\hline$(-)=$ negative capacity inhibition of adhesion to polystyrene; $(+)=$ inhibition of adhesion to polystyrene.
\end{tabular}

\subsection{Confocal Microscopic Observation}

The antibiofilm activity of the crude extracts $(400 \mu \mathrm{g} / \mathrm{mL})$ from Colwellia sp. GW185, Shewanella sp. CAL606 and Winogradskyella sp. CAL396 against P. aeruginosa and S. aureus was also observed onto glass surfaces after $24 \mathrm{~h}$ treatment, by confocal laser scanning microscopic images (Figure 4). The crude extracts from Shewanella sp. CAL606 and Winogradskyella sp. CAL396 showed a visible reduction of the biofilm formation of P. aeruginosa, while Colwellia sp. GW185 did not. The crude extracts from Colwellia sp. GW185, Shewanella sp. CAL606 and Winogradskyella sp. CAL396 were able to inhibit the biofilm formation of S. aureus.

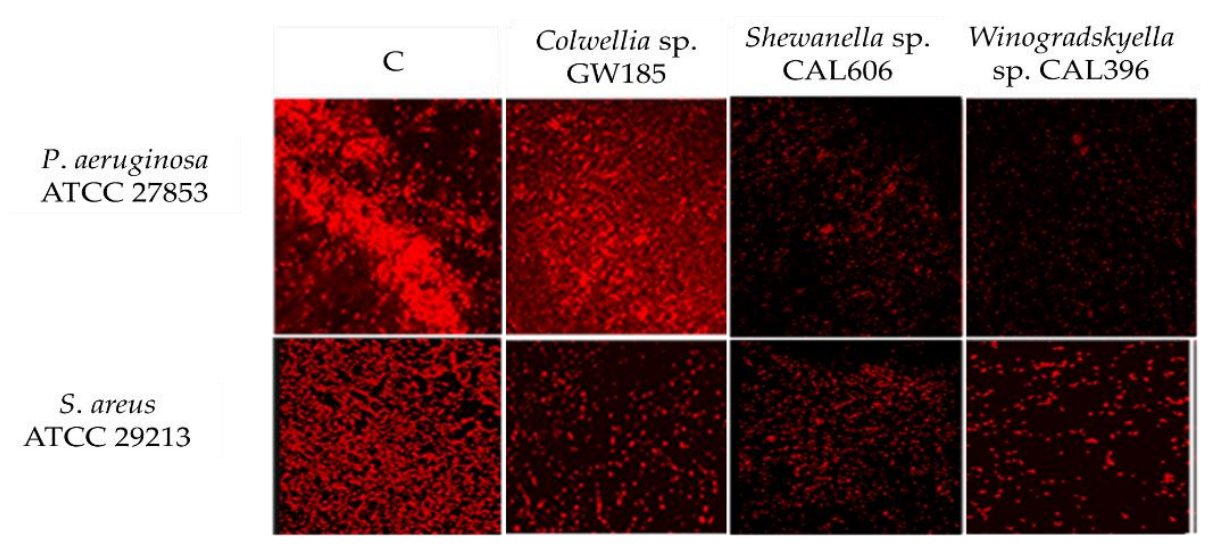

Figure 4. Confocal laser images $(\times 400)$ of biofilm formed by P. aeruginosa ATCC 27853 and S. aureus ATCC 29213 in the absence (Control, C) or in the presence of crude extracts $(400 \mu \mathrm{g} / \mathrm{mL})$ from Colwellia sp. GW185, Shewanella sp. CAL606 and Winogradskyella sp. CAL396 after $24 \mathrm{~h}$ (S. aureus) or 48 h (P. aeruginosa) treatment.

\section{Discussion}

The biofilm formation is relevant in a wide range of domains, from medicine and food industry to marine environmental aspects. Bacterial communities involved in symbiotic relationships with marine invertebrates have recently captured the attention of researchers because they have been proven to be promising for bioprospecting purposes [39]. Even if for a long time many marine invertebrates, and particularly sponges (phylum Porifera), have been considered the direct source of bioactive compounds of therapeutic importance [40,41], more recently it has been demonstrated that the real responsible of metabolite production are their bacterial symbionts [42]. Sponge-associated bacteria may either be transient food sources, symbiotic microbes, or pathogens [43]. It is expected that bacterial symbionts producing bioactive compounds, such as antimicrobial agents or inhibitors of bacterial communication systems (quorum sensing), are able to regulate or prevent the colonization 
by other microorganisms; and therefore, symbiotic relationships provide protection to the microbial symbionts as well as to the host organisms [44]. Classical symbiosis may involve sponge specialists (present in only one species), sponge associated (not found in the surrounding seawaters) or generalists (found in sponges and seawaters) [45]. These aspects were mainly investigated in temperate and tropical areas, while for cold environments, such as Antarctica, it is quite underexplored [21].

The aim of this work was to contribute to search for bacteria associated with Antarctic sponges with applicative perspectives for pharmaceutical and environmental purposes. Eleven cold-adapted strains isolated from Antarctic sponges, belonging to Colwellia, Pseudoalteromonas, Shewanella and Winogradskyella genera, were assayed for their ability to form biofilm, as indicative for the production of extracellular polymeric substances (EPSs) and then for the evaluation of their antibiofilm activity against P. aeruginosa ATCC 27853 and S. aureus ATCC 29213, as model organisms.

All Antarctic strains here investigated were able to form biofilm at both $4{ }^{\circ} \mathrm{C}$ and $25{ }^{\circ} \mathrm{C}$ incubation temperatures, with the best production by Colwellia, Shewanella and Winogradskyella strains at $4{ }^{\circ} \mathrm{C}$ rather than at $25^{\circ} \mathrm{C}$, suggesting that low incubation temperature greatly influence the production of exopolymers in psychrotrophic strains.

The antibiofilm activity of the cell-free supernatants against the two pathogens differed both among strains and on the base of the incubation temperatures, and the major activity was observed by CFSs at $4{ }^{\circ} \mathrm{C}$ against $S$. aureus and at $25^{\circ} \mathrm{C}$ against $P$. aeruginosa, indicating a different action against Gram-positive and Gram-negative bacteria, that are known to produce biofilms with different features [46,47].

CFSs from Colwellia GW 185, Shewanella CAL606 and Winogradskyella CAL 396 were the most active against the biofilm formation by the two pathogens, without demonstrating bactericidal effects on growth, confirming that supernatants acted specifically against the biofilm formation. Similar activity toward staphylococci and P. aeruginosa biofilms have been displayed by cell-free supernatants from different marine bacteria $[18,48]$ and also from cold-adapted bacteria isolated from Arctic and Antarctic seawater samples [27,28,49-52].

To evaluate whether the reduction of the biofilm formation by CFSs produced at different incubation temperatures was due to the inhibition of the initial attachment, surface coating assays were performed. Our results suggested that the CFSs perform antibiofilm activity against $P$. aeruginosa and $S$. aureus at the initial phase of biofilm formation interfering with the cellular adhesion on surfaces (Figure 2). Many molecules with antibiofilm properties act as surfactants, by modifying the bacterial cell physical features and their interaction with abiotic surfaces $[17,53,54]$. Biosurfactants generally alter the surface properties such as wettability and charge and therefore wane bacteria-surface and bacteria-bacteria interactions, reducing the ability to form biofilms $[17,48,55-59]$ The surface tension measurements confirmed the biosurfactant activity of CFSs, although with different effects due to the temperature incubation.

Differences in the antibiofilm activity of CFSs suggest that active molecules produced at different temperatures may differ quantitatively or alternatively may be not identical. A few studies provide evidences that changes in cultivation conditions lead to production of biofilm-specific metabolites and polymers [60-63]. Chemical characterization of crude extracts from the most active CFSs indicated that the strains produced different molecules (Table 5). These bacterial exopolymers have been recently reported to possess attractive properties useful in different biotechnological applications as thickeners and cryoprotectants, and also as bioflocculant, adhesives or antiadhesive, and heavy metals adsorbers for bioremediation purposes $[22,24]$. 
Table 5. Characteristics of exopolymers from Colwellia sp. GW185, Shewanella sp. CAL606 and Winogradskyella CAL396 associated with Antarctic sponges (data from Caruso et al. [26]).

\begin{tabular}{cccc}
\hline & Colwellia sp. GW185 & Shewanella sp. CAL606 & 26 \\
\hline Carbohydrate content (\%) & 28 & 3.0 & 21 \\
\hline Protein content (\%) & 2.08 & 6.07 \\
\hline Uronic acids (\%) & 6.09 & 3.2 \\
\hline $\begin{array}{c}\text { Monosaccharide composition (ratio of } \\
\text { relative portion) }\end{array}$ & $\begin{array}{c}\text { Glu:Man:Gal:GalN:GluA:GalA } \\
(1: 1: 0.7: 0.7: 0.3: t r a c e)\end{array}$ & $\begin{array}{c}\text { Glu:Gal:Man:GalN:GluA:GalA } \\
(1: 1: 0.9: 0.6: 0.3: t r a c e)\end{array}$ & $\begin{array}{c}\text { Man:Ara:GalA:GluA:Gal:Glu:GluN } \\
(1: 0.9: 0.4: 0.3: t r a c e: t r a c e: t r a c e)\end{array}$ \\
\hline $\begin{array}{c}\% \text { Emulsifying activity in hexadecane } \\
\text { (E24) }\end{array}$ & 25 & 60
\end{tabular}

Ara, Arabinose; Glu, Glucose; Gal, Galactose; Man, Mannose; GalN, Galactosamine; GluA, Glucuronic acid; GalA, Galacturonic acid.

The different physical-chemical nature of exopolymers produced by Colwellia sp. GW185, Shewanella sp. CAL606 and Winogradskyella CAL396 can be responsible for their anti-biofilm activity. Results previously reported on the emulsifying activity of these extracts (Table 3) [26] are in agreement with our results in confirming a possible inhibition of the first phase of the biofilm formation. The antiadhesive activity by the crude extracts assessed by microplates assay was also validated by CLSM observations (Figure 4).

Other few bacterial purified EPSs from marine environments, mainly exopolysaccharides, have been reported to possess antibiofilm activities against pathogenic bacteria (Table 6).

Table 6. Bacterial exopolysaccharides with antibiofilm activity against pathogenic bacteria ( ${ }^{\text {a }}$ Caruso et al. [26]).

\begin{tabular}{|c|c|c|c|c|}
\hline Species and Strain & Molecular Weight (kDa) & Main Component & $\begin{array}{c}\text { Anti-Biofilm Activity } \\
\text { against Strain }\end{array}$ & Reference \\
\hline Colwellia sp. GW185 a & Unkown & $\begin{array}{c}\text { Glucose, Mannose, } \\
\text { Galactose, } \\
\text { Galactosamine }\end{array}$ & $\begin{array}{l}\text { Pseudomonas aeruginosa } \\
\text { Staphylococcus aureus }\end{array}$ & This work \\
\hline Shewanella sp. CAL606 a & Unkown & $\begin{array}{c}\text { Glucose, Galactose, } \\
\text { Mannose, } \\
\text { Galactosamine }\end{array}$ & $\begin{array}{l}\text { Pseudomonas aeruginosa } \\
\text { Staphylococcus aureus }\end{array}$ & This work \\
\hline $\begin{array}{l}\text { Winogradskyella sp. } \\
\text { CAL396 a }\end{array}$ & Unkown & $\begin{array}{c}\text { Mannose, Arabinose, } \\
\text { Galacturonic acid }\end{array}$ & $\begin{array}{c}\text { Pseudomonas aeruginosa } \\
\text { Staphylococcus aureus }\end{array}$ & This work \\
\hline Bacillus licheniformis T14 & 1000 & Fructose, Fucose & $\begin{array}{c}\text { Escherichia coli } \\
\text { Klebsiella pneumoniae } \\
\text { Pseudomonas aeruginosa } \\
\text { Staphylococcus aureus }\end{array}$ & [18] \\
\hline Vibrio sp. QY10 & 546 & $\begin{array}{c}\text { Galacturonic acid, } \\
\text { Glucuronic acid, } \\
\text { Rhamnose, } \\
\text { Glucosamine }\end{array}$ & $\begin{array}{l}\text { Pseudomonas aeruginosa } \\
\text { Staphylococcus aureus }\end{array}$ & {$[48]$} \\
\hline Streptococcus phocae PI80 & 280 & Arabinose & $\begin{array}{c}\text { Listeria monocytogenes } \\
\text { Bacillus cereus } \\
\text { Pseudomonas aeruginosa } \\
\text { Staphylococcus aureus } \\
\text { Salmonella thyphi }\end{array}$ & [59] \\
\hline
\end{tabular}

For instance, the exopolysaccharides EPS-T14 produced by Bacillus licheniformis T14 [18] and A101 isolated from the marine Vibrio sp. QY101 [48] were reported to inhibit the initial adhesion of both Gram-negative and Gram-positive bacteria. In addition, the A101 polysaccharide also affected $P$. aeruginosa cell-to-cell interactions and induced biofilm dispersion of $P$. aeruginosa but not of $S$. aureus. Because after the first adhesion bacteria establish strict surface bonds and connections, the initial biofilm formation step can be impacted by several nonbiocidal bacterial activities. 


\section{Conclusions}

Cold-adapted bacteria belonging to Colwellia, Pseudoalteromonas, Shewanella and Winogradskyella genera, isolated from Antarctic sponges, are able to produce exopolymers allowing them to form biofilm as well as to contrast the biofilm formation of Pseudomonas aeruginosa ATCC 27853 and Staphylococcus aureus ATCC 29213, as biofilm models and clinically relevant bacteria. Antibiofilm activity of cell-free supernatants (CFSs) differed among strains and on the basis of their incubation temperature $\left(\mathrm{CFSs}_{4}{ }^{\circ} \mathrm{C}\right.$ and $\left.\mathrm{CFSs}_{25^{\circ}} \mathrm{C}\right)$. The major activity was observed by $\mathrm{CFSs}_{4}{ }^{\circ} \mathrm{C}$ against $S$. aureus and $\mathrm{CFSs}_{25^{\circ} \mathrm{C}}$ against $P$. aeruginosa, without demonstrating a bactericidal effect on their growth.

Our results suggest that both CFSs and crude extracts from Colwellia sp. GW185, Shewanella sp. CAL606, and Winogradskyella sp. CAL396 may act as biosurfactants inhibiting the first adhesion of the two pathogens.

The sponge bacterial symbionts here studied confirm their previously suggested value as novel sources for bioprospecting. Further analyses are envisaged to deeply improve the optimization of production conditions of exopolymers and to investigate the genetic mechanisms at the base of the biofilm inhibition. These exopolymers, as nonbiocidal agents able to prevent the formation of bacterial biofilms, could lead to novel antibiofilm strategies useful in applicative perspectives, spanning from pharmaceutical and medical interests to environmental purposes.

Supplementary Materials: The following are available online at https://www.mdpi.com/2077 $-1312 / 9 / 3 / 243 / \mathrm{s} 1$, Figure S1 Growth expressed as OD600 $\mathrm{nm}$ of the two pathogenic strains (a) P. aeruginosa ATCC 27853 and (b) S. aureus ATCC 29213 in absence (Control, C) or in presence of the CFSs from Antarctic sponges-associated bacteria obtained after incubating at $4{ }^{\circ} \mathrm{C}\left(\mathrm{CFS}_{4^{\circ}} \mathrm{C}\right)$ or $25^{\circ} \mathrm{C}$ $\left(\mathrm{CFS}_{25^{\circ} \mathrm{C}} \mathrm{C}\right.$. Figure S2: Inhibition of P. aeruginosa and S. aureus adhesion to polystyrene surfaces in absence (Control, C) or pre-coated with CFSs from Antarctic sponges-associated bacteria obtained after incubating at $4{ }^{\circ} \mathrm{C}\left(\mathrm{CFS}_{4}{ }^{\circ} \mathrm{C}\right)$ or $25^{\circ} \mathrm{C}\left(\mathrm{CFS}_{25^{\circ}} \mathrm{C}\right)$, after a $18 \mathrm{~h}$ treatment. (a) Colwellia sp., (b) Pseudoalteromonas sp. (c), Shewanella sp. and (d) Winogradskyella sp. Refer to Table 1 for bacterial strain affiliation. Figure S3. P. aeruginosa and S. aureus adhesion to polystyrene surfaces in absence (Control, C) or pre-coated with crude extracts $(400 \mu \mathrm{g} / \mathrm{mL})$ from (a) Colwellia sp. GW185, (b), Shewanella sp. CAL606 and (c) Winogradskyella sp. CAL396 after $18 \mathrm{~h}$ treatment.

Author Contributions: Conceptualization, C.G. and C.R.; methodology, M.G.R., S.G. and V.Z.; validation, C.G., A.L.G.; formal analysis, S.G.; investigation, V.Z., C.R. and M.G.R.; resources, A.S.; P.L. data curation, C.G. and V.Z.; writing - original draft preparation, C.G., S.G. and C.R.; writingreview and editing, C.G.; S.G., M.M. and A.L.G.; supervision, C.G.; funding acquisition, C.G. All authors have read and agreed to the published version of the manuscript.

Funding: This research was supported by grants from PNRA (Programma Nazionale di Ricerche in Antartide), Italian Ministry of Education and Research (Research Projects PNRA 2004/1.6 and PNRA16_00020).

Institutional Review Board Statement: Not applicable.

Informed Consent Statement: Not applicable.

Data Availability Statement: Not applicable.

Conflicts of Interest: The authors declare no conflict of interest.

\section{References}

1. Di Lorenzo, A.; Varcamonti, M.; Parascandola, P.; Vignola, R.; Bernardi, A.; Sacceddu, P.; Sisto, R.; de Alteriis, E. Characterization and performance of a toluene-degrading biofilm developed on pumice stones. Microb. Cell. Fact. 2005, 4, 1-7. [CrossRef]

2. Estrela, C.; Sydney, G.B.; Figueiredo, J.A.P.; de Araújo Estrela, C.R. Antibacterial efficacy of intracanal medicaments on bacterial biofilm: A critical review. J. Appl. Oral Sci. 2009, 17, 1-7. [CrossRef]

3. Laganà, P.; Melcarne, L.; Delia, S. Acinetobacter baumannii and endocarditis, rare complication but important clinical relevance. Int. J. Cardiol. 2015, 187, 678-679. [CrossRef]

4. Liu, C.; Lu, J.; Lu, L.; Liu, Y.; Wang, F.; Xiao, M. Isolation, structural characterization and immunological activity of an exopolysaccharide produced by Bacillus licheniformis 8-37-0-1. Bioresour. Technol. 2010, 101, 5528-5533. [CrossRef] 
5. Melo, W.; Perussi, J.R. Strategies to overcome biofilm resistance. In Microbial Pathogens and Strategies for Combating Them: Science, Technology and Education; Méndez-Vilas, A., Ed.; Formatex Research Center: Badajoz, Spain, 2013; Volume 1, pp. 179-187.

6. Danese, P.N. Antibiofilm approaches: Prevention of catheter colonization. Chem. Biol. 2002, 9, 873-880. [CrossRef]

7. Donlan, R.M.; Costerton, J.W. Biofilms: Survival mechanisms of clinically relevant microorganisms. Clin. Microbiol. Rev. 2002, 15, 167-193. [CrossRef] [PubMed]

8. Hall-Stoodley, L.; Stoodley, P.J. Evolving concepts in biofilm infections. Cell. Microbiol. 2009, 11, 1034-1043. [CrossRef] [PubMed]

9. Høiby, N.; Ciofu, O.; Johansen, H.K.; Song, Z.J.; Moser, C.; Jensen, P.Ø.; Molin, S.; Givskov, M.; Tolker-Nielsen, T.; Bjarnsholt, T.J. The clinical impact of bacterial biofilms. Int. J. Oral Sci. 2011, 3, 55-65. [CrossRef]

10. Monds, R.D.; O’Toole, G.A. The developmental model of microbial biofilms: Ten years of a paradigm up for review. Trends Microbiol. 2009, 17, 73-87. [CrossRef]

11. Flemming, H.C.; Wingender, J.J. The biofilm matrix. Nat. Rev. Microbiol. 2010, 8, 623-633. [CrossRef] [PubMed]

12. Sutherland, I.W. Biofilm exopolysaccharides: A strong and sticky framework. Microbiology 2001, 147, 3-9. [CrossRef] [PubMed]

13. Bazaka, K.; Crawford, R.J.; Nazarenko, E.L.; Ivanova, E.P. Bacterial extracellular polysaccharides. In Bacterial Adhesion; Springer: Berlin/Heidelberg, Germany, 2011; pp. 213-226.

14. Rendueles, O.; Ghigo, J.-M. Mechanisms of competition in biofilm communities. Microbiol. Spectr. 2015, 3, 319-342. [CrossRef]

15. Kim, Y.; Oh, S.; Kim, S.H. Released exopolysaccharide (r-EPS) produced from probiotic bacteria reduce biofilm formation of enterohemorrhagic Escherichia coli O157:H7. Biochem. Biophys. Res. Commun. 2009, 379, 324-329. [CrossRef] [PubMed]

16. Wittschier, N.; Faller, G.; Hensel, A. Aqueous extracts and polysaccharides from liquorice roots (Glycyrrhiza glabra L.) inhibit adhesion of Helicobacter pylori to human gastric mucosa. J. Ethnopharmacol. 2009, 125, 218-223. [CrossRef] [PubMed]

17. Rendueles, O.; Ferrieres, L.; Fretaud, M.; Begaud, E.; Herbomel, P.; Levraud, J.P.; Ghigo, J.M. A new zebrafish model of orointestinal pathogen colonization reveals a key role for adhesion in protection by probiotic bacteria. PLoS Pathog. 2012, 8, e1002815. [CrossRef] [PubMed]

18. Spanò, A.; Lagana, P.; Visalli, G.; Maugeri, T.L.; Gugliandolo, C. In Vitro antibiofilm activity of an exopolysaccharide from the marine thermophilic Bacillus licheniformis T14. Curr. Microbiol. 2016, 72, 518-528. [CrossRef]

19. Guezennec, J.; Herry, J.M.; Kouzayha, A.; Bachere, E.; Mittelman, M.W.; Fontaine, M.N. Exopolysaccharides from unusual marine environments inhibit early stages of biofouling. Biodegradation 2012, 66, 1-7. [CrossRef]

20. More, T.T.; Yadav, J.S.; Yan, S.; Tyagi, R.D.; Surampalli, R. Extracellular polymeric substances of bacteria and their potential environmental applications. J. Environ. Manag. 2014, 144, 1-25. [CrossRef]

21. Lo Giudice, A.; Rizzo, C. Bacteria associated with marine benthic invertebrates from polar environments: Unexplored frontiers for biodiscovery? Diversity 2018, 10, 80. [CrossRef]

22. Lo Giudice, A.; Poli, A.; Finore, I.; Rizzo, C. Peculiarities of extracellular polymeric substances produced by Antarctic bacteria and their possible applications. Appl. Microbiol. Biotechnol. 2020, 104, 2923-2934. [CrossRef]

23. Nichols, C.M.; Guezennec, J.; Bowman, J.J. Bacterial exopolysaccharides from extreme marine environments with special consideration of the Southern Ocean, sea ice, and deep-sea hydrothermal vents: A review. Mar. Biotechnol. 2005, 7, $253-271$. [CrossRef]

24. Caruso, C.; Rizzo, C.; Mangano, S.; Poli, A.; Di Donato, P.; Nicolaus, B.; Di Marco, G.; Michaud, L.; Lo Giudice, A. Extracellular polymeric substances with metal adsorption capacity produced by Pseudoalteromonas sp. MER144 from Antarctic seawater. Environ. Sci. Pollut. Res. Int. 2018, 25, 4667-4677. [CrossRef]

25. Caruso, C.; Rizzo, C.; Mangano, S.; Poli, A.; Donato, P.D.; Nicolaus, B.; Finore, I.; Marco, G.D.; Michaud, L.; Lo Giudice, A. Isolation, characterization and optimization of EPSs produced by a cold-adapted Marinobacter isolate from Antarctic seawater. Antarct. Sci. 2019, 31, 69-79. [CrossRef]

26. Caruso, C.; Rizzo, C.; Mangano, S.; Poli, A.; Di Donato, P.; Finore, I.; Nicolaus, B.; Di Marco, G.; Michaud, L.; Lo Giudice, A. Production and biotechnological potential of extracellular polymeric substances from sponge-associated Antarctic bacteria. Appl. Environ. Microbiol. 2018, 84, e01624-17. [CrossRef]

27. Papa, R.; Selan, L.; Parrilli, E.; Tilotta, M.; Sannino, F.; Feller, G.; Tutino, M.L.; Artini, M. Anti-biofilm activities from marine cold adapted bacteria against Staphylococci and Pseudomonas aeruginosa. Front. Microbiol. 2015, 6, 1333. [CrossRef] [PubMed]

28. Parrilli, E.; Papa, R.; Carillo, S.; Tilotta, M.; Casillo, A.; Sannino, F.; Cellini, A.; Artini, M.; Selan, L.; Corsaro, M.M.; et al. Anti-biofilm activity of Pseudoalteromonas haloplanktis tac125 against Staphylococcus epidermidis biofilm: Evidence of a signal molecule involvement? Int. J. Immunopathol. Pharmacol. 2015, 28, 104-113. [CrossRef] [PubMed]

29. Papaleo, M.C.; Fondi, M.; Maida, I.; Perrin, E.; Lo Giudice, A.; Michaud, L.; Mangano, S.; Bartolucci, G.; Romoli, R.; Fani, R. Sponge-associated microbial Antarctic communities exhibiting antimicrobial activity against Burkholderia cepacia complex bacteria. Biotechnol. Adv. 2012, 30, 272-293. [CrossRef] [PubMed]

30. Mangano, S.; Michaud, L.; Caruso, C.; Lo Giudice, A. Metal and antibiotic resistance in psychrotrophic bacteria associated with the Antarctic sponge Hemigellius pilosus (Kirkpatrick, 1907). Polar Biol. 2014, 37, 227-235. [CrossRef]

31. Savoca, S.; Lo Giudice, A.; Papale, M.; Mangano, S.; Caruso, C.; Spanò, N.; Michaud, L.; Rizzo, C. Antarctic sponges from the Terra Nova Bay (Ross Sea) host a diversified bacterial community. Sci. Rep. 2019, 9, 1-15.

32. Mangano, S.; Michaud, L.; Caruso, C.; Brilli, M.; Bruni, V.; Fani, R.; Lo Giudice, A. Antagonistic interactions between psychrotrophic cultivable bacteria isolated from Antarctic sponges: A preliminary analysis. Res. Microbiol. 2009, 160, 27-37. [CrossRef] 
33. O'Toole, G.A. Microtiter dish biofilm formation assay. J. Vis. Exp. 2011, 47, e2437. [CrossRef]

34. Holmstrom, C.; James, S.; Neilan, B.A.; White, D.C.; Kjelleberg, S. Pseudoalteromonas tunicata sp. nov., a bacterium that produces antifouling agents. Int. J. Syst. Bacteriol. 1998, 48, 1205-1212. [CrossRef] [PubMed]

35. Karwacki, M.T.; Kadouri, D.E.; Bendaoud, M.; Izano, E.A.; Sampathkumar, V.; Inzana, T.J.; Kaplan, J. Antibiofilm activity of Actinobacillus pleuropneumoniae serotype 5 capsular polysaccharide. PLoS ONE 2013, 8, e63844. [CrossRef]

36. Rizzo, C.; Michaud, L.; Graziano, M.; de Domenico, E. Biosurfactant activity, heavy metal tolerance and characterization of Joostella strain A8 from the Mediterranean polychaete Megalomma claparedei (Gravier, 1906). Ecotoxicology 2015, 24, 1294-1304. [CrossRef]

37. Cooper, D.G.; Zajic, J.E.; Gerson, D.F. Production of surface-active lipids by Corynebacterium lepus. Appl. Environ. Microbiol. 1979, 37, 4-10. [CrossRef] [PubMed]

38. Bodour, A.A.; Guerrero-barajas, C.; Jiorle, B.V.; Malcomson, M.E.; Paull, A.K.; Somogyi, A.; Trinh, L.N.; Bates, R.B.; Maier, R.M. Structure and characterization of Flavolipids, a novel class of biosurfactants produced by Flavobacterium sp. strain MTN11. Appl. Environ. Microbiol. 2004, 70, 114-120. [CrossRef] [PubMed]

39. Rizzo, C.; Lo Giudice, A. Marine invertebrates: Underexplored sources of bacteria producing biologically active molecules. Diversity 2018, 10, 52. [CrossRef]

40. Koopmans, M.; Martens, D.; Wijffels, R. Towards commercial production of sponge medicines. Mar. Drugs 2009, 7, 787-802. [CrossRef] [PubMed]

41. Brinkmann, C.; Marker, A.; Kurtböke, D. An overview on marine sponge-symbiotic bacteria as unexhausted sources for natural product discovery. Diversity 2017, 9, 40. [CrossRef]

42. König, H.; Fröhlich, J.; Hertel, H. Diversity and lignocellulolytic activities of cultured microorganisms. In Intestinal Microorganisms of Termites and Other Invertebrates; König, H., Varma, A., Eds.; Springer: Berlin/Heidelberg, Germany, 2006; pp. 271-301.

43. Webster, N.S.; Taylor, M.W. Marine sponges and their microbial symbionts: Love and other relationships. Environ. Microbiol. 2012, 14, 335-346. [CrossRef] [PubMed]

44. Brian-Jaisson, F.; Molmeret, M.; Fahs, A.; Dombrowsky, L.G.; Culioli, G.; Blache, Y.; Cérantola, S.; Ortalo-Magné, A. Characterization and anti-biofilm activity of extracellular polymeric substances produced by the marine biofilm-forming bacterium Pseudoalteromonas ulvae strain TC14. Biofouling 2016, 32, 547-560. [CrossRef]

45. Taylor, M.W.; Schupp, P.J.; Dahllof, I.; Kjelleberg, S.; Steinberg, P.D. Host specificity in marine sponge-associated bacteria, and potential implications for marine microbial diversity. Environ. Microbiol. 2004, 6, 121-130. [CrossRef]

46. Friedman, L.; Kolter, R. Two genetic loci produce distinct carbohydrate-rich structural components of the Pseudomonas aeruginosa biofilm matrix. J. Bacteriol. 2004, 186, 4457-4465. [CrossRef]

47. Joo, H.S.; Otto, M. Molecular basis of in vivo biofilm formation by bacterial pathogens. Chem. Biol. 2012, 19, 1503-1513. [CrossRef] [PubMed]

48. Jiang, P.; Li, J.; Han, F.; Duan, G.; Lu, X.; Gu, Y.; Yu, W. Antibiofilm activity of an exopolysaccharide from marine bacterium Vibrio sp. QY101. PLoS ONE 2011, 6, e18514. [CrossRef] [PubMed]

49. Dheilly, A.; Soum-Soutera, E.; Klein, G.L.; Bazire, A.; Compere, C.; Haras, D.; Dufour, A. Antibiofilm activity of the marine bacterium Pseudoalteromonas sp. strain 3J6. Appl. Environ. Microbiol. 2010, 76, 3452-3461. [CrossRef]

50. Klein, G.L.; Soum-Soutéra, E.; Guedec, Z.; Bazirea, A.; Compere, C.; Dufoura, A. The anti-biofilm activity secreted by a marine Pseudoalteromonas strain. Biofouling 2011, 27, 931-940. [CrossRef] [PubMed]

51. Papa, R.; Parrilli, E.; Sannino, F.; Barbato, G.; Tutino, M.L.; Artini, M.; Selan, L. Anti-biofilm activity of the Antarctic marine bacterium Pseudoalteromonas haloplanktis TAC125. Res. Microbiol. 2013, 164, 450-456. [CrossRef]

52. Parrilli, E.; Ricciardelli, A.; Casillo, A.; Sannino, F.; Papa, R.; Tilotta, M.; Artini, M.; Selan, L.; Corsaro, M.M.; Tutino, M.L. Large-scale biofilm cultivation of Antarctic bacterium Pseudoalteromonas haloplanktis TAC125 for physiologic studies and drug discovery. Extremophiles 2016, 20, 227-234. [CrossRef]

53. Neu, T.R. Significance of bacterial surface-active compounds in interaction of bacteria with interfaces. Microbiol. Rev. 1996, 60, 151-166. [CrossRef]

54. Banat, I.M.; Franzetti, A.; Gandolfi, I.; Bestetti, G.; Martinotti, M.G.; Fracchia, L.; Smyth, T.J.; Marchant, R. Microbial biosurfactants production, applications and future potential. Appl. Microbiol. Biotechnol. 2010, 87, 427-444. [CrossRef]

55. Rodrigues, L.R. Inhibition of bacterial adhesion on medical devices. In Bacterial Adhesion: Biology, Chemistry, and Physics, Series: Advances in Experimental Medicine and Biology; Linke, D., Goldman, A., Eds.; Springer: Berlin, Germany, 2011; Volume 715, pp. 351-367.

56. Walencka, E.; Rozalska, S.; Sadowska, B.; Rozalska, B. The influence of Lactobacillus acidophilus-derived surfactants on staphylococcal adhesion and biofilm formation. Folia Microbiol. 2008, 53, 61-66. [CrossRef]

57. Rivardo, F.; Turner, R.J.; Allegrone, G.; Ceri, H.; Martinotti, M.G. Anti-adhesion activity of two biosurfactants produced by Bacillus spp. prevents biofilm formation of human bacterial pathogens. Appl. Microbiol. Biotechnol. 2009, 83, 541-553. [CrossRef] [PubMed]

58. Valle, J.; Da Re, S.; Henry, N.; Fontaine, T.; Balestrino, D. Broad-spectrum biofilm inhibition by a secreted bacterial polysaccharide. Proc. Natl. Acad. Sci. USA 2006, 103, 12558-12563. [CrossRef] 
59. Kanmani, P.; Satish Kumar, R.; Yuvaraj, N.; Paari, K.A.; Pattukumar, V.; Arul, V. Production and purification of a novel exopolysaccharide from lactic acid bacterium Streptococcus phocae PI80 and its functional characteristics activity in vitro. Bioresour. Technol. 2011, 102, 4827-4833. [CrossRef]

60. Beloin, C.; Valle, J.; Latour-Lambert, P.; Faure, P.; Kzreminski, M.; Balestrino, D.; Haagensen, J.A.; Molin, S.; Prensier, G.; Arbeille, B.; et al. Global Impact of Mature Biofilm Lifestyle on Escherichia coli K-12 Gene Expression. Mol. Microbiol. 2004, 51, 659-674. [CrossRef] [PubMed]

61. Matz, C.; Webb, J.S.; Schupp, P.J.; Phang, S.Y.; Penesyan, A.; Egan, S.; Steinberg, P.; Kjelleberg, S. Marine biofilm bacteria evade eukaryotic predation by targeted chemical defense. PLoS ONE 2008, 3, e2744. [CrossRef] [PubMed]

62. Valle, J.; Da Re, S.; Schmid, S.; Skurnik, D.; d'Ari, R.; Ghigo, J.-M. The amino acid valine is secreted in continuous-flow bacterial biofilms. J. Bacteriol. Res. 2008, 190, 264-274. [CrossRef]

63. Colvin, K.M.; Gordon, V.D.; Murakami, K.; Borlee, B.R.; Wozniak, D.J.; Wong, G.C.L.; Parsek, M.R. The pel polysaccharide can serve a structural and protective role in the biofilm matrix of Pseudomonas aeruginosa. PLoS Pathog. 2011, 7, e1001264. [CrossRef] 